\title{
Successful aging as a multidimensional concept: An integrative review
}

\author{
Nasibeh Zanjari ${ }^{1}$, Maryam Sharifian Sani ${ }^{2 *}$, Meimanat Hosseini Chavoshi ${ }^{3}$, Hassan Rafiey ${ }^{2}$, \\ Farahnaz Mohammadi Shahboulaghi ${ }^{4}$
}

Received: 6 Jun $2106 \quad$ Published: 17 Dec 2017

\begin{abstract}
Background: Successful aging as an umbrella term with a large amount of literature has emerged with a variety of meanings and dimensions in different studies. This article aims at determining what dimensions contribute to constructing the concept of successful aging.

Methods: The method used in this study is an integrative review of published literature related to successful aging. This method includes both qualitative and quantitative studies. Data searching was conducted during November and December 2014 and was then updated in October 2015. First, 2543 articles were identified, and after the screening phase, 76 articles were eligible for inclusion in the integrative review.

Results: The results specified 14 subcategories and 5 main categories of successful aging: social well-being, psychological wellbeing, physical health, spirituality and transcendence, and environment and economic security.

Conclusion: The present study provides a thorough understanding of successful aging dimensions and proposes the importance of the multidimensional concept of successful aging at the individual, interpersonal, and environmental levels for future studies and policymaking on population aging.
\end{abstract}

Keywords: Successful aging, Integrative review, Multidimensional, Well-being

Copyright@ Iran University of Medical Sciences

Cite this article as: Zanjari N, Sharifian Sani M, Hosseini Chavoshi M, Rafiey H, Mohammadi Shahboulaghi F. Successful aging as a multidimensional concept: An integrative review. Med J Islam Repub Iran. 2017 (17 Dec);31:100. https://doi.org/10.14196/mjiri.31.100

\section{Introduction}

The public and academic attention given to aging was increased significantly at the beginning of the 21 st century due to the increase of life expectancy and population aging in most countries. Based on United Nations projection (2015), the number of people aged 60 years or over would grow by $56 \%$ from 901 million $(12.3 \%$ of the total population) in 2015 to 1.4 billion ( $16.5 \%$ of the total population) by 2030 in the world. Hence, the term "successful aging" emerged in the literature to describe the notion of aging well.

Successful aging as an umbrella term overlaps with a

Corresponding author: Dr Maryam Sharifian Sani, ma.sharifian@uswr.ac.ir

1. Iranian Research Center on Aging, University of Social Welfare and Rehabilitation Sciences, Tehran, Iran.

2. Department of Social Welfare, University of Social Welfare and Rehabilitation Sciences, Tehran, Iran.

3. School of Population and Global Health, University of Melbourne, Melbourne, Australia.

4. Department of Nursing, University of Social Welfare and Rehabilitation Sciences, Tehran, Iran. variety of concepts such as positive aging, aging well, productive aging, and healthy aging. One of the fundamental issues underlying the debate is how successful aging should be defined by objective criteria or is it a subjective value judgment (1). Some researchers suggested that the concept of successful aging (SA) was introduced by Harvighurst as maximum satisfaction in the 1960s (2). Some others mentioned Cicero, and in gerontology Cumming and Henry (1961) (1). In 1997, Rowe and Kahn suggested successful aging as avoiding disease and disability, high cognitive and physical functioning, and engagement

$\uparrow$ What is "already known" in this topic:

Despite a large literature on successful aging, there is no general agreement on the dimensions of successful aging.

\section{$\rightarrow$ What this article adds:}

The concept of successful aging consists of 5 main categories: social well-being, psychological well-being, physical health, spirituality and transcendence, and environment and economic security. A comprehensive understanding of successful aging can be used in future studies, interventions, and policymaking to promote aging well. 
with life (3). Following the Rowe and Kahn definition and framework, MacArthur studies started as a large attempt to study objective successful aging and distinguish successful agers using physical and cognitive cut-off scores $(4,5)$. Another popular model of successful aging is the SOC model, which was introduced by Baltes and Baltes to demonstrate how older adults adjust to aging. They stated that success is an individual development comprising 3 main components: selection, optimization, and compensation $(6,7)$.

Nonetheless, in reality, many of the old people imagine themselves as successful agers despite their disability and health problems such as diabetes or hypertension $(8,9)$. Thus, successful aging includes other dimensions $(10,11)$. Also, the cross-cultural perspective of successful aging has an important role in the definition of successful aging conceptual framework $(9,12)$. More models of successful aging have been explored by both quantitative (13-17) and qualitative (18-22) research designs. Also, in recent years, some new terms have been suggested for successful aging such as gerotranscendence (23) and harmonious aging (24). Despite a large literature on successful aging, some of the researches have mentioned that there is no general agreement on the dimensions of successful aging (11). Therefore, this article aimed at exploring the dimensions of successful aging using an integrative study.

\section{Methods}

The method used in this study was an integrative review of published articles related to successful aging. This methodology is the broadest type of research review method and allows concurrent inclusion of quantitative and qualitative research to allow a fuller understanding of a phenomenon of concern (successful aging). Integrative reviews may also merge/synthesize data from theoretical and empirical studies (25). Whittemore and Knafl (2005) introduced an integrative approach framework consisting of 5 stages including problem identification, literature search, data evaluation, data analysis (results), and presentation (conclusion) to enhance the accuracy of the process when conducting an integrative review. The data from successful aging reviews were coded, categorized, and compiled into the matrix.

\section{- Problem identification}

Although aging is a natural process in our life, individuals can become involved in creating a successful aging process rather than the passive experience of later life. Thus, a discussion about successful aging converges with the search for factors and conditions that help us to understand the potential of aging, and if desirable, to identify ways to modify the nature of human aging as it exists today (6). The focus of this study was to answer the following question: What dimensions contribute to constructing the concept of successful aging?

\section{- Literature search}

The second stage of an integrative review is a literature search. Data searches were conducted during November and December 2014, and then updated in October 2015. A comprehensive search was conducted using the following electronic databases: ProQuest, EBSCO, JSTOR, PubMed, ISI, and Scopus. The keyword "successful* aging" was used with both spellings of ageing and aging.

The inclusion criteria for the study were the term "Successful aging" in the title with the aforementioned spellings and abstracts including terms such as "model*," "definition," "theory*," "structure*," "dimension*," and "perception"; the full-text articles were available and to prevent overlapping, we excluded other phrases such as healthy aging and aging well.

\section{- Data evaluation}

This integrative study aimed at exploring the current knowledge about the dimensions of successful aging. Thus, in the screening, articles that explained just 1 specific dimension of successful aging such as medical factors,

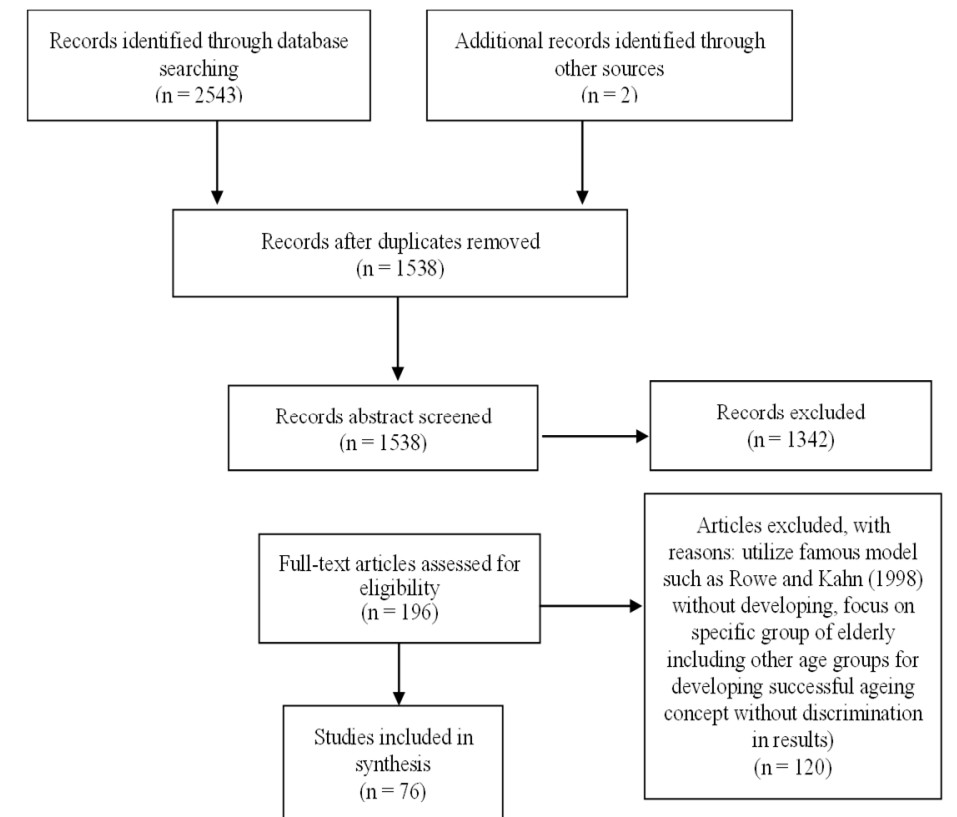

Fig. 1. The number of identified and included articles in the study 
or those that focused on a specific group of older adults such as the elderly with chronic diseases or depression were excluded from the study. Moreover, studies that included young people's perception of constructing the concept of successful aging were excluded. Fig. 1 demonstrates the number of identified and included articles in this study.

In the data search, 2543 articles were initially identified, and after screening, 76 articles were eligible for inclusion in the study. A total of 34 articles used quantitative or mixed methods and 42 studies used qualitative methods or a literature review.

\section{Results}

In this study, a matrix was developed by the authors outlining the year, country, population, and dimension of successful aging (Tables A and B in the Appendix). The articles included in the study were published between 1960 and 2015, and most of them had been conducted in the recent years. The most frequent articles in the field of successful aging were conducted in the United States. Many of the quantitative articles employed survey or second data analysis and follow-up methods. Although quantitative studies place more emphasis on physical/mental health and social engagement, in qualitative researches the

Table 1. Dimensions of successful aging extracted from integrative review

\begin{tabular}{|c|c|c|c|}
\hline Main categories & Subcategories & Codes & Meaning summary \\
\hline \multirow[t]{6}{*}{ Social well-being } & \multirow[t]{3}{*}{$\begin{array}{l}\text { Social presence \& } \\
\text { interaction }\end{array}$} & $\begin{array}{l}\text { Close relationship with } \\
\text { others }\end{array}$ & $\begin{array}{l}\text { Family relationship, a network of friends and family, intergenerational } \\
\text { relationship, doing some activities with family }\end{array}$ \\
\hline & & Social activity & $\begin{array}{l}\text { Productive activity or job, volunteer activity, social teaching, self- } \\
\text { employment, participating in public activity }\end{array}$ \\
\hline & & Recreation & Traveling, creative activities, having variety of hobbies \\
\hline & \multirow[t]{3}{*}{ Social support } & Not lonely & Having a partner, wife/husband for close relationship and engagement \\
\hline & & $\begin{array}{l}\text { Social support from } \\
\text { family }\end{array}$ & $\begin{array}{l}\text { Having a friend for speaking to or traveling, emotional and financial } \\
\text { support from family, visiting family }\end{array}$ \\
\hline & & $\begin{array}{l}\text { Social support from } \\
\text { governments }\end{array}$ & $\begin{array}{l}\text { Social welfare policy for older adults, sufficient healthcare system, facili- } \\
\text { tation of social role and productive activity for older adults, sufficient } \\
\text { pension, and insurance }\end{array}$ \\
\hline \multirow{18}{*}{$\begin{array}{l}\text { Psychological well- } \\
\text { being }\end{array}$} & \multirow{11}{*}{$\begin{array}{l}\text { Individual positive } \\
\text { characteristics and } \\
\text { capabilities }\end{array}$} & Happiness & Being full of energy and happy, joyful \\
\hline & & $\begin{array}{l}\text { Having purpose/plan } \\
\text { and hope }\end{array}$ & Being hopeful, having aims for the future \\
\hline & & Positive mood & $\begin{array}{l}\text { Generous, curious, sense of humor, other positive characteristics based on } \\
\text { culture }\end{array}$ \\
\hline & & Being useful & No feeling of worthlessness, being productive, feeling of usefulness \\
\hline & & Good appearance & Good figure, being stylish \\
\hline & & Self-acceptance & Good feeling about his/herself, self-confidence, feeling of being useful, \\
\hline & & Self-efficacy & $\begin{array}{l}\text { Ability for self-care, ability to avoid risk factors, ability to recover from } \\
\text { disease }\end{array}$ \\
\hline & & Mastery & $\begin{array}{l}\text { Ability to change environment in his/her interest, ability to do complex } \\
\text { activity in life and family, ability to change or select property environ- } \\
\text { ment for his/her physical or mental limitation }\end{array}$ \\
\hline & & Maintaining balance & $\begin{array}{l}\text { Balance between opportunity and challenges, selection of alternatives, } \\
\text { compensation, balance between body and mind, balance between aspira- } \\
\text { tions and goals achieved }\end{array}$ \\
\hline & & Coping and resilience & $\begin{array}{l}\text { Ability to face life problems and challenges, avoiding running away from } \\
\text { problems, adoption of aging limitations, avoiding the wrong solutions }\end{array}$ \\
\hline & & Continuity in learning & $\begin{array}{l}\text { Learning new things, attempting to improve knowledge, attention to } \\
\text { development in later life }\end{array}$ \\
\hline & \multirow[t]{2}{*}{ Lifespan satisfaction } & $\begin{array}{l}\text { Satisfaction with past } \\
\text { life }\end{array}$ & $\begin{array}{l}\text { Acceptance of past life, good job, good memories from the past, satisfac- } \\
\text { tion, and getting over bad memories such as war }\end{array}$ \\
\hline & & life satisfaction & Satisfaction with whole life, satisfaction with partner \\
\hline & \multirow[t]{2}{*}{$\begin{array}{l}\text { Positive self- } \\
\text { perception of aging }\end{array}$} & $\begin{array}{l}\text { Acceptance of the } \\
\text { natural process of } \\
\text { aging }\end{array}$ & Acceptance of transition and changes from aging, acceptance of decline \\
\hline & & $\begin{array}{l}\text { Positive perception } \\
\text { towards aging }\end{array}$ & $\begin{array}{l}\text { Acceptance of positive points of aging, good self-image, without any bad } \\
\text { image such as frail elderly }\end{array}$ \\
\hline & \multirow[t]{3}{*}{$\begin{array}{l}\text { Absence of mental } \\
\text { illness }\end{array}$} & No depression & $\begin{array}{l}\text { No signs of depression, such as withdrawal, feelings of worthlessness and } \\
\text { being useless, despair }\end{array}$ \\
\hline & & $\begin{array}{l}\text { No cognitive impair- } \\
\text { ment }\end{array}$ & $\begin{array}{l}\text { No signs or symptoms of Alzheimer's and Parkinson suspicion of having } \\
\text { attention problems, no language impairment }\end{array}$ \\
\hline & & No stress or phobia & $\begin{array}{l}\text { Anorexia or stress eating, fear of the death of someone close, feeling } \\
\text { guilty }\end{array}$ \\
\hline \multirow[t]{6}{*}{ Physical health } & \multirow[t]{2}{*}{$\begin{array}{l}\text { Good physical } \\
\text { health }\end{array}$} & $\begin{array}{l}\text { Positive self-rated } \\
\text { health status }\end{array}$ & No pain, no feeling of fatigue and feeling healthy and well \\
\hline & & $\begin{array}{l}\text { The absence of various } \\
\text { diseases }\end{array}$ & $\begin{array}{l}\text { No symptoms of disease such as heart disease, heart attack, diabetes, } \\
\text { cancer, emphysema, osteoporosis, asthma, hypertension, obesity, cardio- } \\
\text { vascular disease, lung disease, Parkinson's disease }\end{array}$ \\
\hline & \multicolumn{2}{|c|}{ Avoidance of risk factors } & $\begin{array}{l}\text { No smoking, eating Mediterranean diet, physical fitness and doing exer- } \\
\text { cises such as stretching }\end{array}$ \\
\hline & \multirow[t]{3}{*}{$\begin{array}{l}\text { Functional } \\
\text { health }\end{array}$} & daily living activities & $\begin{array}{l}\text { Doing personal activities such as taking a shower, ability to make phone } \\
\text { call, shopping, climbing stairs }\end{array}$ \\
\hline & & sence of disability & No hearing, visual, or physical impairment \\
\hline & & & Living to more than 80 or 85 years old \\
\hline
\end{tabular}




\begin{tabular}{|c|c|c|c|}
\hline \multicolumn{4}{|l|}{ Table 1. Cntd } \\
\hline \multirow[t]{5}{*}{$\begin{array}{l}\text { Spirituality and } \\
\text { transcendence }\end{array}$} & Spirituality & & $\begin{array}{l}\text { Feeling of inner peace, being thankful, being religious, accepting a } \\
\text { superior power, having beliefs }\end{array}$ \\
\hline & Gerotranscendence & Self-transcendence & Rationality, self-recognition, decrease of self-orientation \\
\hline & & Ontology & $\begin{array}{l}\text { Feeling of being part of world, part of life cycle, change of viewpoint } \\
\text { on the world }\end{array}$ \\
\hline & & Acceptance of death & Reduction of stress from death, change of viewpoint on death \\
\hline & & Solitude & Thinking about secret of life and relation with ancestors \\
\hline \multirow{5}{*}{$\begin{array}{l}\text { Environment } \\
\text { and economic } \\
\text { security }\end{array}$} & $\begin{array}{l}\text { Appropriate context and } \\
\text { environmental amenity }\end{array}$ & $\begin{array}{l}\text { Favorite living neigh- } \\
\text { borhood }\end{array}$ & $\begin{array}{l}\text { Feeling of social security for walking in neighborhood, good ac- } \\
\text { commodation with sufficient heat and light }\end{array}$ \\
\hline & & $\begin{array}{l}\text { Accommodation in the } \\
\text { good zone of the city }\end{array}$ & Nice weather, clean water, having sufficient garbage disposal system \\
\hline & & $\begin{array}{l}\text { living in a good envi- } \\
\text { ronment with accessibil- } \\
\text { ity to healthcare system } \\
\text { age-friendly city }\end{array}$ & Near to hospital, proper transportation to healthcare system \\
\hline & & $\begin{array}{l}\text { Absence of negative } \\
\text { stereotype in society }\end{array}$ & $\begin{array}{l}\text { Absence of negative image of elderly in media avoids marginalizing } \\
\text { the social role of the elderly }\end{array}$ \\
\hline & $\begin{array}{l}\text { Financial and economic } \\
\text { security }\end{array}$ & \multicolumn{2}{|c|}{ Satisfaction with financial resources, sufficient pension, or assets and having a home } \\
\hline
\end{tabular}

theme of satisfaction with life is more common.

During data analysis, dimensions of successful aging concept in the articles were coded and categorized. The results are presented as codes, subcategories, and main categories in Table 1. The dimensions are summarized in the matrix and include 14 subcategories and 5 main categories: physical health, social well-being, psychological well-being, spirituality, and environment and economic security.

\section{1) Physical health}

The main category of physical health includes 3 subcategories: good physical health, avoidance of risk factors, and functional health. An assessment of physical health is frequently performed in most studies on successful aging, particularly in quantitative research. Researchers of aging explore both self-rated health and the disease history of older adults $(16,26)$. Physical health assessment in the considerations is named as an objective (1) or medical dimension (27). Avoidance of risk factor is another subcategory related to healthy behaviors such as a Mediterranean diet and exercise (26). Moreover, in the qualitative studies, older adults indicated that avoidance of risk factor was an important dimension of aging well (22). Functional health is another significant factor of successful aging that indicates the ability to do daily activities $(28,29)$. Longevity was mentioned in some studies, but recently some studies mentioned that quality of life is more significant than longevity $(9,30,31)$.

\section{2) Psychological well-being}

The main category of psychological well-being included 4 subcategories: absence of mental illness, individual positive characteristics and capabilities, lifespan satisfaction, and positive self-perception of aging. Absence of mental illness is one of the most important subcategories and has usually been studied in the absence of depression and dementia $(15,32)$. Individual positive characteristics and capabilities is one of the subcategories, which contains a variety of initial codes such as mastery, selfacceptance, happiness, having an aim and purpose in life, and being in a positive mood $(14,20,21,33)$. It seems that the codes of this category are flexible in different cultural contexts. Lifespan satisfaction is one of the subcate- gories interwoven with successful aging from Havighurst's efforts to conceptualize successful aging. Satisfaction of the elderly is not only related to their present life but also to memories and past life (34). The codes that construct the positive self-perception of aging subcategory emerged from qualitative studies that revealed older adults with a positive aging perception accepted the natural cycle of life and aging but tried to feel young at heart $(19,35)$.

3) Social well-being

Social well-being is another main category and is based on 2 subcategories: presence in the society/community and having social support. Presence in the society means having a close relationship with others, doing social activities, and engaging in recreation $(19,30,36)$. Social support is defined at 3 levels: individual (e.g., not being lonely), family (e.g., emotional or instrumental support), and government (e.g., social welfare policy for the elderly). Family social support is an important element and provides a buffer against depression and stress in later life.

\section{4) Spirituality and transcendence}

Spirituality and transcendence is one of the latest dimensions of successful aging in the literature. Spirituality is defined as having beliefs or accepting a higher power and being thankful (9). Crowther et al. (37) revised Rowe and Kahn's model of successful aging and added spirituality as the fourth dimension of successful aging. Gerotranscendence is the second subcategory that emerges in the successful aging literature as a new and partly complicated concept. Gerotranscendence includes factors such as self-transcendent, ontology, and accepts death and solitude. Gerotranscendence theory indicates that older adults transfer from a rational view to a more cosmic one in their third stage of life $(23,38)$.

\section{5) Environment and economic security}

The main category of environment and economic security indicates a good relationship between the elderly and external factors. The subcategory "appropriate context and environmental amenity" can be categorized at the neighborhood level as well as at macro levels such as living in an appropriate environment with nice weather, infrastructure facilities, and health systems $(10,27,39)$. In successful aging literature, less attention is given to social con- 


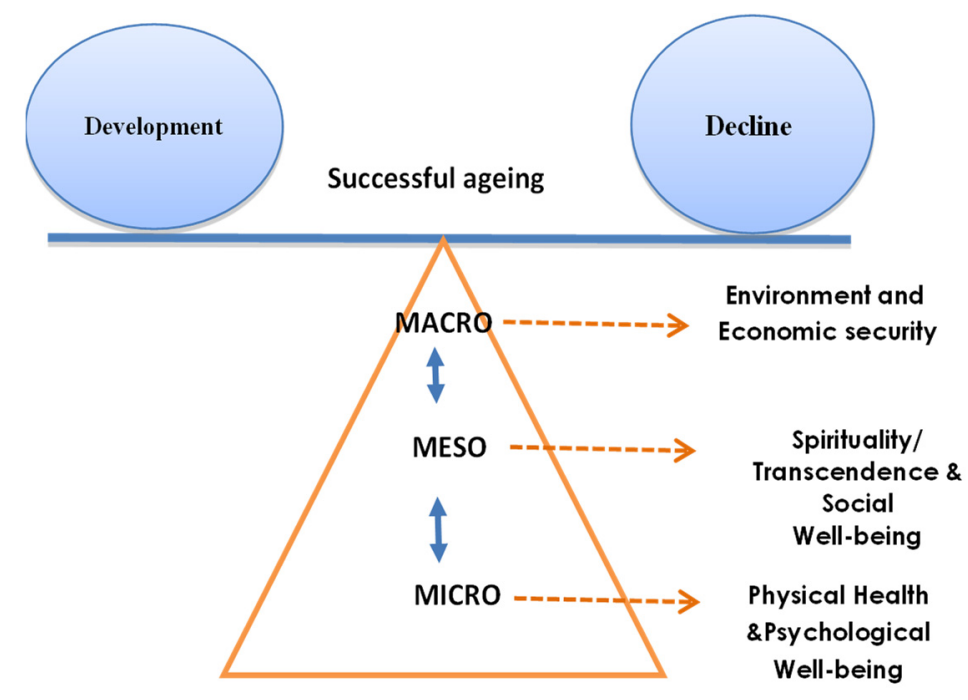

Fig. 2. Balance in "successful aging" concept

texts such as absence of negative stereotypes, which can shape a desirable living environment for the elderly (19). The last subcategory is financial sufficiency through pensions, governmental support, or individual property, which is known to be a basic need for aging well $(40,41)$.

\section{Discussion}

This study aimed at exploring the dimensions of successful aging using an integrative review. The results revealed 5 main categories (social well-being, psychological well-being, physical health, spirituality and transcendence, and environment and economic security) and 14 subcategories for successful aging. According to the main categories and subcategories, the 4 following characteristics of successful aging concept are suggested:

Multidimensional: Successful aging is not a singledimensional concept that only focuses on physical aspects, but it consists of social, psychological, spiritual/ transcendent, and economic and environmental aspects. This is consistent with the existing literature on successful aging that emphasizes the multidimensional nature of successful aging $(15,42)$.

Life course: Successful aging does not emerge spontaneously in the third stage of life (late life). In fact, it is the fruit of the previous life stages. Aging successfully is based on the past life conditions of the elderly $(6,43)$.

Multilevel: The results showed successful aging to be a multilevel concept. The definition starts with an underlying individual level such as individual characteristics and continues to a higher level such as structural and environmental amenity. In other words, it covers many determinants at different levels from micro to macro levels of successful aging.

Contextual: The concept of successful aging is sensitive to culture. As Torres (1999) noted, the elderly have different viewpoints from a variety of cultures in the meaning of a good old age. While Chinese older adults define it in terms of how others view them, elderly Americans define successful aging in terms of how they view the world (44).
As Baltes (1987) emphasized in his theory of lifespan development, "Throughout life, development always consists of the joint occurrence of gain (growth) and loss (decline)." (45, p.616). With regard to the results of the present study, the concept of successful aging is constructed with individual and social elements. The elderly try to maintain a balance between losses such as physical decline and gains such as transcendency in their later life. The balance between development and decline is attained by having individual, social, and environmental resources. In other words, balance means having physical health and psychological well-being at the micro level, having social well-being, and spirituality/transcendence at the meso level, and living in an appropriate environment with economic security (Fig. 2)

Therefore, successful aging is a multidimensional and multilevel concept. As Bowling and Dieppe (2005) stated, "Achievement of successful aging in terms of all the criteria presented (here) is unrealistic for most people. However, successful aging needs to be viewed, not only multidimensionally, but as an ideal state to be aimed for, and the concept itself should be placed on a continuum of achievement rather than subject to simplistic normative assessments of success or failure." (8, p.1550).

\section{Conclusion}

The present study clarifies the dimension of success in later life from among the huge body of literature on successful aging. Given the extent of this concept and the cultural nature of successful aging, there is no integrative definition of successful aging. In previous studies, the focus was on physical dimensions and less attention was given to the multidimensional approach. Recently, other dimensions of successful aging, particularly psychological aspects and other levels of successful aging including interpersonal and environmental dimensions, have been drawn to researchers' attention. The results of this study suggested the importance of successful aging at the individual, interpersonal, and environmental levels in the def- 
inition of the multidimensional viewpoint of successful aging. Moreover, the findings of this study allow a thorough understanding of the dimensions of successful aging, which can be applied in future studies and interventions on older adults' well-being and policymaking on population aging.

\section{Conflict of Interests}

The authors declare that they have no competing interests.

\section{References}

1. Pruchno RA, Wilson-Genderson M, Cartwright F. A two-factor model of successful aging. J Gerontol B Psychol Sci Soc Sci. 2010;65 (6):671-9.

2. Havighurst RJ. Successful aging. Gerontologist, 1961; 1:8-13.

3. Rowe JW, Kahn RL. Successful aging. Gerontologist. 1997;37 (4):433.

4. Berkman LF, Seeman TE, Albert M, Blazer D, Kahn R, Mohs R, et al. High, usual and impaired functioning in community-dwelling older men and women: findings from the MacArthur Foundation Research Network on Successful Aging. J Clin Epidemiol. 1993;46(10):112940

5. Cernin PA, Lysack C, Lichtenberg PA. A comparison of self-rated and objectively measured successful Agingaging constructs in an urban sample of African American older adults. Clin Gerontol. 2011;34(2):89-102.

6. Baltes P, Baltes M. Psychological perspectives on successful aging: the model of selective optimisation with compensation. Successful aging: perspectives from the behavioral sciences. New york: Cambridge University Press; 1990.

7. Martin P, Kelly N, Kahana B, Kahana E, B JW, Willcox DC, et al. Defining successful aging: a tangible or elusive concept? Gerontologist. 2015;55(1):14-25.

8. Bowling A, Dieppe P. What is successful aging and who should define it? BMJ. 2005;331:1548-1551.

9. Tate RB, Loewen BL, Bayomi DJ, Payne BJ. The consistency of definitions of successful aging provided by older men: The Manitoba Follow-up Study. Can J Aging. 2009;28(4):315-22.

10. Hsu H-C. Exploring elderly people's perspectives on successful aging in Taiwan. Ageing Soc. 2007;27(1):87-102.

11. Cosco TD, Prina AM, Perales J, Stephan BCM, Brayne C. Operational definitions of successful aging: a systematic review. Int Psychogeriatr. 2014;26(3):373-81.

12. Phelan EA, Anderson LA, LaCriox AZ, Larson EB. Older adults' views of "successful aging" -- how do they compare with researchers' definitions? Journal of the American Geriatrics Society. 2004;52 (2):211-6.

13. Doyle YG, McKee M, Sherriff M. A model of successful aging in British populations. Eur J Public Health. 2012;22 (1):71-6.

14. Jeon SN, Shin H, Lee HJ. Dynamics of constructs in successful Agingaging of Korean elderly: modified Rowe and Kahn's Model. Osong Public Health Res Perspect. 2012;3(3):137-44.

15. Lee PL, Lan W, Yen TW. Aging successfully: a four-factor model. Educ Gerontol. 2011;37(3):210-27.

16. Tate RB, Swift AU, Bayomi DJ. Older men's lay definitions of successful Agingaging over time: The Manitoba Follow-Up Study. Int J Aging Hum Dev. 2013;76 (4):297-322.

17. Young Y, Frick KD, Phelan EA. Can successful aging and chronic illness coexist in the same individual? A multidimensional concept of successful aging. J Am Med Dir. 2009;10(2):87-92.

18. Hörder HM, Frändin K, Larsson MEH. Self-respect through the ability to keep the fear of frailty at a distance: successful aging from the perspective of community-dwelling older people. Int J Qual Stud Health Well-being. 2013; 8:20194-20204.

19. Jopp DS, Wozniak D, Damarin AK, De Feo M, Jung S, Jeswani S. How could lay perspectives on successful aging complement scientific theory? Findings from a U.S. and a German life-span sample. Gerontologist. 2014;55(1):91-106.

20. Zanjari N, Sharifian Sani M, Hosseini Chavoshi M, Rafiey H, Mohammadi Shahboulaghi F. Perceptions of successful aging among Iranian elders: insights from a qualitative study. Int J Aging Hum
Dev 2016:83(4):381-401.

21. Reichstadt J, Sengupta G, Depp CA, Palinkas LA, Jeste DV. Older adults' perspectives on successful aging: qualitative interviews. Am J Geriatr Psychiatry 2010;18(7):567-75.

22. Troutman-Jordan M, Staples J. Successful Aging from the viewpoint of older adults. Res Theory Nurs Pract. 2014;28(1):87-104.

23. Tornstam L. Gerotranscendence: the contemplative dimension of aging. J Aging Stud. 1997;11(2):143-54.

24. Liang J, Luo B. Toward a discourse shift in social gerontology: from successful aging to harmonious aging. J Aging Stud. 2012; 26(3):32734.

25. Whittemore $\mathrm{R}$, Knafl $\mathrm{K}$. The integrative review: updated methodology. J Adv Nurs. 2005;52(5):546-53.

26. Tyrovolas S, Haro JM, Mariolis A, Piscopo S, Valacchi G, Tsakountakis $\mathrm{N}$, et al. Successful aging, dietary habits and health status of elderly individuals: a k-dimensional approach within the multi-national MEDIS study. Exp Gerontol. 2014;60: 57-63.

27. Cosco TD, Brayne C, Matthew Prina A, Perales J, Stephan BCM. Whose "successful aging"? Lay- and researcher-driven conceptualisations of aging well. Eur. Psychiatry. 2014;28(2):124-30.

28. Hodge AM, English DR, Giles GG, Flicker L. Social connectedness and predictors of successful aging. Maturitas. 2013;75(4):361-6.

29. Thielke S, Diehr P. Transitions among health states using 12 measures of successful aging in men and women: results from the Cardiovascular Health Study. J Aging Res. 2012;2012.

30. Hilton JM, Gonzalez CA, Saleh M, Maitoza R, Anngela-Cole L. Perceptions of successful aging among older Latinos, in cross-cultural context. J Cross Cult Gerontol. 2012;27(3):183-99.

31. Knight T, Ricciardelli LA. Successful aging: perceptions of adults aged between 70 and 101 years. Int J Aging Hum Dev. 2003;56(3):223-45.

32. Parslow RA, Lewis VJ, Nay R. Successful aging: development and testing of a multidimensional model using data from a large sample of older Australians. J Am Geriatr Soc. 2011;59(11):2077-83.

33. Baltes MM, Carstensen LL. The process of successful aging. Ageing Soc. 1996;16:397-422.

34. Craciun C. Successful aging-Utopia or the result of lifelong learning? Meaning and representations of aging in Romanian elderly. Aging International. 2012;37(4):373-85.

35. Swift AU, Tate RB. Themes from older men's lay definitions of successful aging as indicators of primary and secondary control beliefs over time: The Manitoba Follow-up Study. J Aging Stud 2013;27(4):410-8

36. Nguyen AL, Seal DW. Cross-cultural comparison of successful aging definitions between Chinese and Hmong elders in the United States. J Cross Cult Gerontol. 2014;29(2):153-71.

37. Crowther MR, Parker MW, Achenbaum WA, Larimore WL, Koenig HG. Rowe and Kahn's model of successful aging revisited positive spirituality — the forgotten factor. Gerontologist. 2002;42(5):613-20.

38. Topaz M, Troutman-Jordan M, MacKenzie M. Construction, deconstruction, and reconstruction: the roots of successful Agingaging theories. Nurs Sci Q. 2014;27(3):226-33.

39. Hsu H, Tsai C, Chang M, Luh D. Constructing area-level indicators of successful aging in Taiwan. Health Soc Care Community. 2010;18(1):70-81.

40. Bowling A. Lay perceptions of successful aging: findings from a national survey of middle-aged and older adults in Britain. Eur $\mathrm{J}$ Ageing. 2006;3(3):123.

41. Wang YT, Lin WI. Successful aging: the case of Taiwan. Australas J Ageing. 2012;31(3):141-6.

42. Cosco TD, Prina AM, Perales J, Stephan BCM, Brayne C. Lay perspectives of successful aging: a systematic review and metaethnography. BMJ. 2013;3(6).

43. Schulz R, Heckhausen J. A life span model of successful aging. Am Psychol. 1996;51(7):702-14.

44. Torres S. A culturally-relevant theoretical framework for the study of successful aging. Ageing Soc. 1999;19(1):33.

45. Baltes PB. Theoretical propositions of life-span developmental psychology: on the dynamics between growth and decline. Dev Psychol. 1987;23(5):611-626. 
Table A. Quantitative and mixed studies of successful aging

\begin{tabular}{|c|c|c|c|c|c|}
\hline No. & $\begin{array}{l}\text { Author name \& } \\
\text { year of study }\end{array}$ & Type of study & Population & Country & Dimensions of successful aging \\
\hline 1 & $\begin{array}{l}\text { Cho et al } \\
(2015)\end{array}$ & $\begin{array}{l}\text { Sequential study } \\
\text { (Structural equation } \\
\text { modelling) }\end{array}$ & $\begin{array}{l}375 \text { centenarians } \\
(98+) \text { and octoge- } \\
\text { narians }(80-89 \\
\text { years old })\end{array}$ & USA & $\begin{array}{l}\text { Physical functioning, having no physical health impairment, education, } \\
\text { past life experience, cognitive functioning, social resources, perceived } \\
\text { economic status. }\end{array}$ \\
\hline 2 & $\begin{array}{l}\text { Cheung and } \\
\text { Lau(2015) }\end{array}$ & $\begin{array}{l}\text { Cross-sectional data } \\
\text { analysis }\end{array}$ & $120(95-108)$ & China & $\begin{array}{l}\text { Physical and functional health, Psychological well-being and cognition, } \\
\text { Social engagement and family support, and Economic resources and } \\
\text { financial security }\end{array}$ \\
\hline 3 & $\begin{array}{l}\text { Cosco et al } \\
(2015)\end{array}$ & $\begin{array}{l}\text { Population-based } \\
\text { study }\end{array}$ & $740(65+)$ & UK & $\begin{array}{l}\text { Physical functioning and cognitive Functioning, personal resources, } \\
\text { engagement, and self-awareness }\end{array}$ \\
\hline 4 & $\begin{array}{l}\text { Tyrovolas et al } \\
\quad(2015)\end{array}$ & Survey (2005-2011) & $\begin{array}{l}2,663 \text { older }(\text { aged } \\
65-100 \text { years old) }\end{array}$ & Greece & $\begin{array}{l}\text { Education, financial status, physical activity status, BMI, psychological } \\
\text { level, participation in social activities with friends and family, yearly } \\
\text { excursions, the burden of CVD risk factors, and dietary habits }\end{array}$ \\
\hline 5 & Gasiorek(2015) & $\begin{array}{l}\text { Second data analy- } \\
\text { sis(Latent class } \\
\text { analysis across of } \\
\text { two datasets }\end{array}$ & $\begin{array}{l}692(40-82 \text { years } \\
\text { old })\end{array}$ & $\begin{array}{l}\text { New Zealand } \\
\text { and USA }\end{array}$ & $\begin{array}{l}\text { Subjective approach (answer to questions: How successfully have you } \\
\text { aged up to now? How well are you aging? How do you rate your life } \\
\text { these days? I am happy with the age I am right now; at my age, I feel that } \\
\text { life has much to offer, and I'm as happy at this stage of my life as I have } \\
\text { been at other points in time) }\end{array}$ \\
\hline 6 & $\begin{array}{c}\text { Feng et } \\
\text { al(2015) }\end{array}$ & $\begin{array}{l}\text { Comparative } \\
\text { study(longitudinal } \\
\text { survey) }\end{array}$ & $19,346(65+)$ & $\begin{array}{l}\text { China and } \\
\text { Korea }\end{array}$ & $\begin{array}{l}\text { Free from major illness and disability, having no depressive or symptom, } \\
\text { participating in social or productive activities, and being satisfied with } \\
\text { life }\end{array}$ \\
\hline 7 & $\begin{array}{l}\text { Tyrovolas et } \\
\mathrm{al}(2014)\end{array}$ & Follow-up study & $\begin{array}{l}2663 \text { elderly (aged } \\
65-100 \text { years old) }\end{array}$ & $\begin{array}{l}21 \text { Mediter- } \\
\text { ranean Is- } \\
\text { lands }\end{array}$ & $\begin{array}{l}\text { Psychosocial economic factors(education, financial status, social activity } \\
\text { with friends, Social activities with family, going to excursions, GDS } \\
\text { score); Clinical characteristics factors(CVD risk score, Body mass index); } \\
\text { Lifestyle characteristics factors(Med-Diet Score, Frequency of daily } \\
\text { physical activities) }\end{array}$ \\
\hline 8 & $\begin{array}{c}\text { Tovel and } \\
\text { Carmel(2014) }\end{array}$ & Cross-sectional study & $262(75+)$ & Israel & $\begin{array}{l}\text { Subjective well-being measured by Positive Morale Scale ( Agitation, } \\
\text { Attitude toward aging, Lonely, dissatisfaction), Life Satisfaction } \\
\text { Scale(resolution, congruence, self-concept and mood tone) and Happiness } \\
\text { Scale }\end{array}$ \\
\hline 9 & Li et al (2014) & $\begin{array}{l}\text { Population-based } \\
\text { cross-sectional study }\end{array}$ & $903(65+)$ & Taiwan & $\begin{array}{l}\text { SF-36 The SF-36 PCS and MCS scales (physical functioning, social } \\
\text { functioning, role limitations due to physical problems, role limitations } \\
\text { due to emotional problems, mental health, vitality, pain, and general } \\
\text { perception of health }\end{array}$ \\
\hline 10 & Tate et al(2013) & $\begin{array}{l}\text { Content analysis } \\
\text { from Manitoba } \\
\text { Follow-up Study and } \\
\text { Generalized Linear } \\
\quad \text { Mode }\end{array}$ & $\begin{array}{l}2,043 \text { men were } \\
\text { alive at a mean } \\
\text { age of } 78 \text { years in } \\
1996\end{array}$ & Canada & 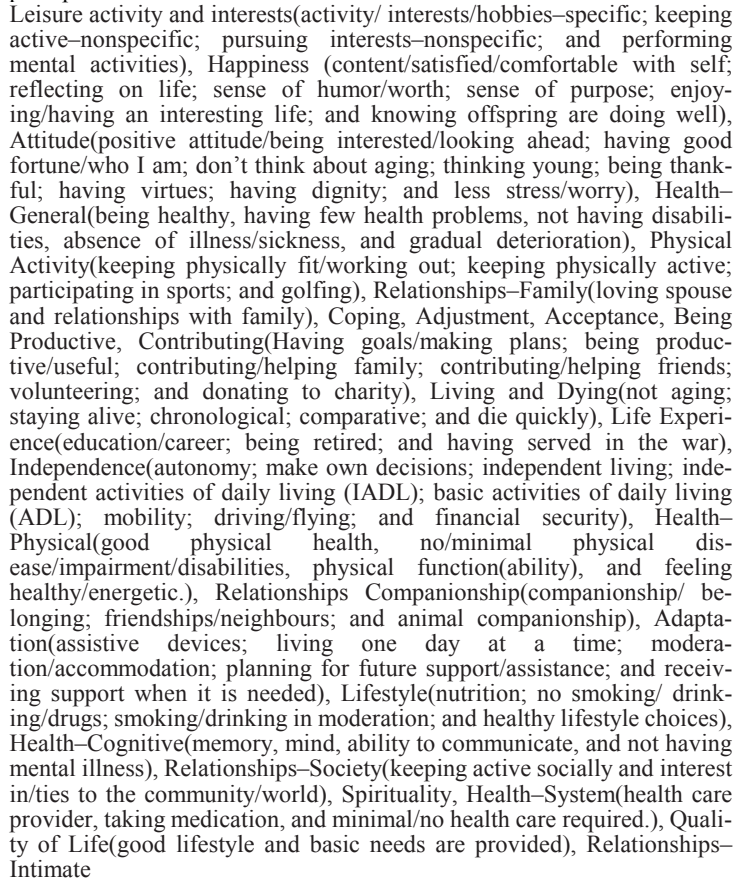 \\
\hline 11 & $\begin{array}{l}\text { Hodge et } \\
\text { al(2013) }\end{array}$ & Cohort study & $\begin{array}{l}5512 \text { older } \\
\text { adults }(70+)\end{array}$ & Australia & $\begin{array}{l}\text { Who had survived to age } 70 \text { years, who at follow-up study reported none } \\
\text { of: diabetes, heart attack, coronary artery bypass graft surgery, angioplas- } \\
\text { ty, stroke, or had a cancer (excluding non-melanoma skin cancer), im- } \\
\text { pairment, or perceived major difficulty with physical functioning(SF-12), } \\
\text { without having any limitation in moderate activities (such as moving a } \\
\text { table, pushing a vacuum cleaner, bowling, or playing golf), or having a lot } \\
\text { of limitation in climbing several flights of stairs, no difficulty in using a } \\
\text { telephone or perform the following instrumental activities of daily living: } \\
\text { shopping, walking } 200 \mathrm{~m} \text {, getting out by car or public transport by them- } \\
\text { selves, going up stairs or doing heavy work around the house such as } \\
\text { shovelling dirt or washing walls. Without psychological distress such as } \\
\text { depression and anxiety(Kessler scale) }\end{array}$ \\
\hline
\end{tabular}




\begin{tabular}{ccccc}
\hline Table A. Cntd & & \\
\hline 12 & Swift and & Manitoba Follow-up & 2043(74-88 years & Canada \\
& Tate(2013) & Study: thematic & old) & \\
& codes of an open & & \\
& question and corre- & & \\
& lation &
\end{tabular}

Primary control proper ( Health care provider, Taking medication Education/career, Having served in the war Having/accomplishing goals/making plans, Assistive devices , Moderation/accommodation, Being productive/useful Contributing/helping family Contributing/helping friends, Volunteering Donating to charity, Keeping physically fit/working out, Keeping physically active, Participating in sports, Golfing, Activity/interests/hobbies, Keeping active, Pursuing interests, Performing mental activities, Healthy nutrition, No smoking/drinking/drugs, Smoking/drinking in moderation, Healthy lifestyle choices, Independence - autonomy, Independence - make own decisions, Independence - independent living, Independence - instrumental activities, Independencebasic activities, Independence - mobility, Independence - driving/flying, Independence - financial)

Limited primary control(Being healthy, Having few health problems, Absence of illness/sickness, Gradual deterioration, Good physical health, No/minimal physical disease/impairment, Physical functional ability, Feeling healthy/energetic, Memory, Mind Ability to communicate, Minimal/no health care required, Not aging, Staying alive, Comparative age, Being retired Good, lifestyle, Basic needs provided, Getting support when needed)

Pertinent to primary control(Not having disabilities, Not having mental illness, Reaching old age, Dying quickly)

Secondary control proper(Positive attitude, Having good fortune, Don't think Secondary control proper(Positive attitude, Having good fortune, Don't think about aging, Thinking young, Being thankful, Knowing offspring are doing
well, Coping with personal stressors, Coping with family/friend's declining health/death, Adjusting to wife's/friend's declining health/death, Accepting changing body, Accepting the "natural progression" of life, Accepting wife's/friend's declining health/death, Loving spouse, Relationships with family, Companionship/belonging — non-specific, Friendships/neighbors, Animal companionship, Intimate relationships, Keeping active socially, Interest in/ties to the community/world, Being spiritual/having faith, Sense of purpose, Planning for future support/assistance, Sense of meaning and purpose)

Limited secondary control(Having virtues, Having dignity, Sense of huLimited secondary control(Having virtues, Having dignity, Sense of hu-
mor/worth, Enjoying/having an interesting life, Less stress/worry, Conmor/worth, Enjoying/having an interesting life, Less st
tent/satisfied/comfortable with self, Living one day at a time)

\begin{tabular}{|c|c|c|c|}
\hline 13 & $\begin{array}{l}\text { Gwee et al } \\
\quad(2013)\end{array}$ & $\begin{array}{c}\text { Cross-sectional data } \\
\text { analysis }\end{array}$ & $\begin{array}{l}489 \text { community- } \\
\text { dwelling }(65+)\end{array}$ \\
\hline 14 & $\begin{array}{l}\text { Jeon et al } \\
(2012)\end{array}$ & $\begin{array}{c}\text { Cross-sectional data } \\
\text { analysis }\end{array}$ & $\begin{array}{l}600 \text { older adults } \\
(65+)\end{array}$ \\
\hline 15 & $\begin{array}{l}\text { Hilton et } \\
\text { al(2012) }\end{array}$ & $\begin{array}{l}\text { multi-method } \\
\text { approach }\end{array}$ & $\begin{array}{l}60 \text { older Latinos } \\
(50+)\end{array}$ \\
\hline 16 & $\begin{array}{l}\text { Thielke and } \\
\text { Diehr(2012 } \\
\text { ) }\end{array}$ & $\begin{array}{l}\text { Population-based } \\
\text { longitudinal study }\end{array}$ & 5888 adults $(65+$ \\
\hline 17 & $\begin{array}{l}\text { Lee et al } \\
\text { (2011) }\end{array}$ & Survey & $\begin{array}{l}312 \text { participants } \\
\text { aged } 65+\end{array}$ \\
\hline 18 & $\begin{array}{c}\text { Tan et } \\
\operatorname{al}(2011)\end{array}$ & $\begin{array}{c}\text { Survey (Phe- } \\
\text { lan(2004)questionnai } \\
\text { re used) }\end{array}$ & $\begin{array}{c}\text { Anglo-Australian } \\
\text { and } 116 \text { Chinese- } \\
\text { Australian }(60+\end{array}$ \\
\hline 19 & $\begin{array}{l}\text { Parslow et } \\
\text { al (2011) }\end{array}$ & Second data analysis & $\begin{array}{l}2286 \text { elders }(61 \text { tc } \\
85 \text { years old })\end{array}$ \\
\hline 20 & $\begin{array}{l}\text { Bowling } \\
\text { and } \\
\text { Iliffe(2011) }\end{array}$ & $\begin{array}{l}\text { Postal follow-up in } \\
2007 / 8 \text { of a } 999 \\
\text { people }\end{array}$ & $\begin{array}{l}287 \text { national } \\
\text { random sam- } \\
\text { ple }(65+)\end{array}$ \\
\hline
\end{tabular}

Singapore Self-rated SA on an analogue scale from 1 to 10 and five specific dimensions (physical health and function, mental well-being, social engagement, psychological well-being, and spirituality/religiosity)

Modified Rowe and Kahn model: self-reported health(Healthy habits, Subjective health, chronic diseases), social network(emotional support, instrumental support) physical-cognitive function, psychological trait(life satisfaction, self-

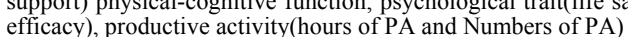

efficacy), productive activity(hours of PA and Numbers of PA) Quantitative results: highest and lowest rankings based on Phelan questions:
act on inner standards, feel good about self, good health, cope with aging challenges, sense of peace about the end of life, friends and family support, no regrets, stay involved with world and others, able to work, longevity.

Qualitative results: positive attitude, independence, good health, stay involved with life, social relationships/family, cognitive functioning, self-care, acceptance, financial well-being, spirituality/religion/transcendence

Psychological, physical, cognitive, and functional status(not hospitalized, no bed days, life satisfaction, life as a whole, not depressed, no limitations in activities of daily living, no limitations in independent activities of daily living, intact extremity strength, Self-rated health, Intact cognition, Ability to ambuintact extremity strength,
late, Frequent ambulation

late, Frequent ambulation Physical(physical condition over the past two weeks), psychological(psychological symptoms of depression and stress), social support(personal interaction with others), leisure time(frequency of engaging in intense exercises or activities and frequency of out-of-town traveling during the past 12 months)

Australia Rated as an important aspect among both Chinese and Anglo-Australians: physical health and functioning, the absence of disability and disease, staying physical health and functioning, the absence of disability and disease, staying
engaged with life, adjusting to changes, being able to make choices and having friends and family.

Latent variable of successful aging: Self-assessed physical and mental Health(general health question), life satisfaction(Delighted- Terrible scale), and cognitive function(MMSE score)

Biomedical (having diagnosed, chronic medical conditions; ability to perform activities of daily living (ADL), psychiatric morbidity(GHQ-12)); Broader biomedical(number of different social activities engaged in during past month) Social functioning(number of different social activities engaged in during past Social functioning(number of different social activities engaged in during past
month, frequency of social contacts, number of helpers/supporters); Psychologmonth, frequency of social contacts, number of helpers/supporters); Psycholog-
ical resources(self-efficacy, sense of purpose, playing useful part, coping, facing up to problems, overcoming difficulties; self-esteem, feels has selfconfidence and has self-worth); Lay(gross annual income and perceived social capital, rating of area facilities transport, closeness to shops, services, area problems, crime, vandalism, graffiti, speed and volume of traffic, air quality, somewhere nice to go for a walk, feels safe walking alone during the day or night)

\begin{tabular}{|c|c|c|c|c|}
\hline 21 & $\begin{array}{l}\text { Wang and } \\
\operatorname{lin}(2011)\end{array}$ & $\begin{array}{l}\text { Cross-section na- } \\
\text { tional } \\
\text { survey }\end{array}$ & $1309(65+)$ & Taiwan \\
\hline 22 & $\begin{array}{c}\text { Doyle et } \\
\text { al }(20 \\
10)\end{array}$ & $\begin{array}{l}\text { Longitudinal study } \\
\text { with follow-up data }\end{array}$ & $\begin{array}{l}3005 \text { members } \\
\text { aged } 50+\end{array}$ & UK \\
\hline 23 & $\begin{array}{l}\text { Pruchno et } \\
\text { al 2010)( }\end{array}$ & $\begin{array}{l}\text { Data analysis from a } \\
\text { Panel study }(2006 \\
\text { and 2008) }\end{array}$ & $\begin{array}{c}\text { from } 5,688 \text { per- } \\
\text { sons aged } 50-74 \\
\text { years } 01 d\end{array}$ & USA \\
\hline
\end{tabular}

Physical health(self-rated health, self-reported ability to stand up), mental health(depression) social/productive engagements(having paid jobs, no. of weekly hours in paid work, no. of weekly hours in volunteer work, social support) economic security(current financial condition, economic sufficiency during retirement)

Objective: avoidance of disease and related risk factors, maintenance of high function and sustained engagement with life

Subjective: process of selection, optimization and compensation/confidence(optimal well-being as outcome)

Objective: functional ability, pain, number of diseases

Subjective: aging well, life rating(self-rated) 


\begin{tabular}{|c|c|c|c|c|c|}
\hline 24 & $\begin{array}{c}\text { Hsu et } \\
\text { al(2010) }\end{array}$ & $\begin{array}{c}\text { Secondary data } \\
\text { analysis (modified } \\
\text { Delphi method and } \\
\text { analytical } \\
\text { hierarchy process) }\end{array}$ & $\begin{array}{l}23 \text { city(4624 older } \\
\text { adults) }\end{array}$ & $\begin{array}{l}\text { Taiwan } \\
\end{array}$ & $\begin{array}{l}\text { Area-level indicators of Successful aging: health status(chronic disease prevalence, } \\
\text { chronic disease screening, healthy aging), health lifestyle(smoking, drinking, chew- } \\
\text { ing betel nuts, exercise, diet) health care resources and utilization(disease prevention } \\
\text { and medical utilization, medical resources, long-term care resources) social partici- } \\
\text { pation(employment and productive activities, economic security, education, com- } \\
\text { munity development, volunteer) social environment(safety, infrastructure) natural } \\
\text { environment(air, water, garbage disposal) }\end{array}$ \\
\hline 25 & $\begin{array}{l}\text { Pin Ng et } \\
\text { al(2009) }\end{array}$ & $\begin{array}{l}\text { Cross-sectional and } \\
\text { longitudinal data } \\
\text { analysis }\end{array}$ & $\begin{array}{l}1281 \text { older } \\
\text { adults }(65+)\end{array}$ & Singapore & $\begin{array}{l}\text { Functioning and wellness: cognitive and affective status(MMSE and GDS), physical } \\
\text { health(self-reported health and IADL), social functioning and engagement(the level } \\
\text { of participation (often or at least once a week) engaging with at least one listed } \\
\text { social or productive activities including social, recreational, civic activities, volun- } \\
\text { tary work, and paid employment or business, and domestic activities) and life satis- } \\
\text { faction(self-reported of interest in life, happiness, loneliness, and general ease of } \\
\text { living) }\end{array}$ \\
\hline 26 & $\begin{array}{r}\text { Tate et } \\
\text { al(2009) }\end{array}$ & $\begin{array}{l}\text { Manitoba Follow-up } \\
\text { Study }\end{array}$ & 734 Men older adults & Canada & $\begin{array}{l}\text { Health (physical, mental, and cognitive health); health behaviours (physical and } \\
\text { mental activity or interests including health care and lifestyle); having life (longevi- } \\
\text { ty, being alive, and resistance to aging); productivity (being useful, contributing, } \\
\text { volunteering); independence (in mobility and self-care); spirituality/faith (in what- } \\
\text { ever way stated); acceptance/adaptation (including coping mechanisms); social } \\
\text { networks(family/ friends, and social activity); life experience(earlier choices in } \\
\text { occupations, education, and retirement to support quality of life) }\end{array}$ \\
\hline 27 & $\begin{array}{c}\text { Jang et } \\
\text { al(2009) }\end{array}$ & Survey & $\begin{array}{l}1825 \text { persons aged } \\
65+\end{array}$ & $\begin{array}{l}\text { The } \\
\text { Republic } \\
\text { of Korea }\end{array}$ & $\begin{array}{l}\text { Physical functioning (chronic diseases and ADL scale), mental functioning (history } \\
\text { of mental Disease and MMSE scale), social functioning(social activity participation } \\
\text { per week) subjective well-being( PGCMS scale) }\end{array}$ \\
\hline 28 & $\underset{8)}{\operatorname{Kahng}(200}$ & $\begin{array}{l}\text { Second data analysis } \\
\text { of Americans' } \\
\text { Changing Lives } \\
\text { (ACL) data }\end{array}$ & $\begin{array}{l}683 \text { older adults } \\
(65+)\end{array}$ & USA & $\begin{array}{l}\text { Physical health(chronic health condition, functional health, physical health), mental } \\
\text { health(depressive symptoms, cognitive impairment, self-efficacy), engagement with } \\
\text { life(formal social integration, informal social integration, social support from } \\
\text { friends and relatives) }\end{array}$ \\
\hline 29 & $\begin{array}{c}\text { Bowl- } \\
\text { ing }(2006)\end{array}$ & Second data analyses & $\begin{array}{l}854 \text { older adults } \\
(50+)\end{array}$ & UK & $\begin{array}{l}\text { Health and functioning; psychological factors; social roles and activities; financial } \\
\text { and living circumstances; Social relationships; neighborhood/community; work; } \\
\text { independence }\end{array}$ \\
\hline 30 & $\begin{array}{l}\text { Li et al } \\
(2006)\end{array}$ & Cross-sectional & $\begin{array}{l}100000 \text { older } \\
\text { adults }(65+)\end{array}$ & China & $\begin{array}{l}\text { Chinese version of functional health (MMSE), activities of daily living (ADL), the } \\
\text { Life Satisfaction (LSIA), functional social support (DUFSS), leisure activities, } \\
\text { healthy behaviours, negative life events, health (SF-36) }\end{array}$ \\
\hline 31 & Hsu(2007) & $\begin{array}{l}\text { Qualitative and } \\
\text { quantitative method }\end{array}$ & 720 elderly & Taiwan & $\begin{array}{l}\text { physical health and independence(living without chronic disease), economic securi- } \\
\text { ty, family and social support(living with family and receiving emotional care), } \\
\text { engagement with life, spiritual well-being, and environment and social welfare } \\
\text { policy }\end{array}$ \\
\hline 32 & $\begin{array}{l}\text { Phelan et al } \\
\quad(2004)\end{array}$ & $\begin{array}{l}\text { Cross- } \\
\text { sectional(mailed } \\
\text { survey) }\end{array}$ & $\begin{array}{l}1985 \text { Japanese Amer- } \\
\text { ican elders and } 2581 \\
\text { white men and wom- } \\
\text { en }(65+)\end{array}$ & USA & $\begin{array}{l}\text { Physical health, functioning, psychological/mental health(perception of autonomy, } \\
\text { control and coping), social health }\end{array}$ \\
\hline 33 & $\begin{array}{l}\text { Tate et al } \\
(2003)\end{array}$ & $\begin{array}{l}\text { The Manitoba Fol- } \\
\text { low-up Study: con- } \\
\text { tent analysis and } \\
\text { correlation }\end{array}$ & $\begin{array}{l}\text { 3983(The mean age } \\
\text { at entry was } 31 \text { after } \\
50 \text { years follow-up (a } \\
\text { mean age of } 78 \text { ) }\end{array}$ & Canada & $\begin{array}{l}\text { Health and disease(good health or less pain, visits to physicians, and having check- } \\
\text { ups), physical activity, keeping mentally active, Keeping socially, keeping active in } \\
\text { general ( Keeping active (unspecified), keep busy, keep going, keep working), } \\
\text { happy life or satisfying lifestyle ( Happiness, enjoy life, satisfying lifestyle, don't } \\
\text { worry, retirement(quite work)), positive outlook on life or having a positive atti- } \\
\text { tude(Positive outlook, attitude, interest in life, Having close and loving family and } \\
\text { friends(Have a loving spouse, family, and friends), spiritual component, accepting } \\
\text { growing old(growing old gracefully, peace of mind, tranquillity), Independence } \\
\text { (being able to carry on, lead a normal life, make own decisions, mobile, do whatever } \\
\text { you want, keep up responsibilities), Recognition of necessity for moderation (to } \\
\text { decline gradually, limitations, adjust capabilities), A component encompassing } \\
\text { mention of diet or eating (eating (includes all ingestible: smoking, drinking, vita- } \\
\text { mins), good appetite), having goals or challenges(travel), being financially secure, } \\
\text { having hobbies or interests(having various interests, activities), being useful (volun- } \\
\text { teering, helping others, being productive), being content(having a sense of hu- } \\
\text { mor(laughing)), miscellaneous(staying alive) }\end{array}$ \\
\hline 34 & $\begin{array}{l}\text { Ford et } \\
\text { al(2000) }\end{array}$ & Followed up & $\begin{array}{l}602 \text { older adults } \\
(70+)\end{array}$ & USA & $\begin{array}{l}\text { Sustained Independence: receiving no help, in the form of either formal (paid) or } \\
\text { informal (unpaid) service, with any of the personal or instrumental ADLs during the } \\
2 \text {-year observation period(A total of } 17 \text { activities, including seven personal care } \\
\text { tasks(feeding self, dressing, grooming, transferring, bathing, toileting and walking), } \\
\text { seven instrumental activities(use of telephone, transportation, shopping, meal prepa- } \\
\text { ration, housework, taking medication and handling money), plus three self- } \\
\text { designated, highly valued activities such as going to church or recreational activi- } \\
\text { ties, Visits to physicians and hospital admissions }\end{array}$ \\
\hline 35 & $\begin{array}{l}\text { Straw- } \\
\text { bridge and } \\
\text { e al(1996) }\end{array}$ & longitudinal study & 356 older adults & USA & $\begin{array}{l}\text { Ability to do } 13 \text { basic physical activities: bathing, eating, dressing, grooming, using } \\
\text { the toilet, walking across a room, transferring from bed to chair, shopping, cooking, } \\
\text { doing housework, walking a half mile ( } 0.8 \mathrm{~km}) \text {, walking up a flight of stairs, and } \\
\text { having no problem getting where they needed to go. ability to do five physical } \\
\text { performance activities: lifting or carrying weights over } 10 \text { pounds ( } 4.54 \mathrm{~kg}) \text {; stoop- } \\
\text { ing, crouching, or kneeling; pushing or pulling a large object (like a living room } \\
\text { chair); Lifting arms above the shoulders, and writing or handling small objects. }\end{array}$ \\
\hline
\end{tabular}


An integrative review of successful aging

Table B. Qualitative and review studies of successful aging

\begin{tabular}{cccccc}
\hline No. & $\begin{array}{c}\text { Author name \& } \\
\text { year of study }\end{array}$ & Type of study & Population & Country & Dimensions of successful aging \\
\hline 1 & Chen(2015) & $\begin{array}{c}\text { Constant com- } \\
\text { parative method } \\
\text { Basic review }\end{array}$ & $\begin{array}{c}14 \text { older fe- } \\
\text { male(60+) }\end{array}$ & Taiwan & $\begin{array}{l}\text { Being healthy, having no financial worries, maintaining connections with family and friends, } \\
\text { contributing to society, and desiring a good death, not longevity } \\
\text { Avoid disease and disability, optimal health activities, access to healthcare, healthy environ- }\end{array}$
\end{tabular}

3 Sato-Komata et Grounded $15(85+) \quad \begin{aligned} & \text { Avoid disease and disability, optimal health activities, access to } \\ & \text { ment, engagement with life, high physical and cognitive function }\end{aligned}$

15(85+) Japan Conflict over declining functions(sensation of loss of physical and cognitive function, fear of , acceptance or denial of health condition, need to feet th condition, realisation of having aged compared to earlier years) relationship with the aging body(personal effort to maintain one's physical condition, essential medical treatment), reflection on self (gratitude, outlook toward living a long life, distinct views on objects, desiring few objects and goals); reflection on daily life(mundaneness of everyday life, economic factors of daily life, acceptance of daily life, objects to look forward); reflection on society(acknowledgment of the value of one's relationships, wish to be useful to society, interest in modern society); reflection on life and preparation for death(Reminiscence of life, Preparations for the future, ideal way of living, ideal way of dying)

Death(not being afraid of death, an easy death, a nice death, a painless death), a balanced and harmonious life(living in harmony, a rich life, a balanced life, a normal life, a happy life, living in peace), independence(physical independence, financial independence, autonomy and decision-making and self-mastery), life circumstances(Environment(a nice home and not being institutionalized), a sense of security, freedom from responsibilities, no transitions of care, not being alone) physical(Mobility: Ability to walk, good mobility, (good function care, not being alone) physical(Mobility: Ability to walk, good mobility, (good function
activities: doing exercise and being physically active, health: good physical condition, not activities: doing exercise and being physically active, health: good physical condition, not
smoking, not having pain), cognitive and psychological(Mental health, absence of dementia, feeling good (mentally), absence of depression or cognitive problems, no painful memories, happiness and joy, preserving one's own personality, accepting reality, self-acceptance and self-contentment and focusing on the present, accepting others, a positive outlook and a positive attitude, tolerance, coping and adaptation and adjustment, maintaining an interest, humility, self-esteem, self-rect, satisfaction (with life), a calm personality, no argum, hils learning new things and having a good memory) social(social network: family, friends, children, grandchildren, good neighbours, being surrounded by people and having company, dren, grandchildren, good neighbours, being surrounded by people and having company, having a partner and a good marriage, not being alone), Social roles(doing things for the family(taking care of grandchildren or a partner), helping others, being a member of an organization, having social interactions and relationships with others), recreation and entertain-
ment(going out with others, having hobbies, keeping going, listening to music, visiting family)

Jopp et al (2015) Qualitative approach

$306(16+)$ and

USA and Health(health in general, health behaviour, physical fitness, mental health), social resources(care-related aspects, have social, feeling of social embeddedness/belonging resources, Social engagement/participation), activities/interests(activity without further specification, cognitive activities, work/job-related activities, sports, hobbies travel, culture/creativity, volunteering/unpaid engagement) virtues/attitudes/beliefs(positive attitude about life, acvolunteering/unpaid engagement) virtues/attitudes/beliefs(positive attitude about life, ac-
ceptance, openness/curiosity, self-esteem, self-efficacy, be good to self, other psychological ceptance, openness/curiosity, self-esteem, self-efficacy, be good to self, other psychological
characteristics), well-being(well-being/satisfaction/happiness/fulfilment, enjoying life) life characteristics), well-being(well-being/satisfaction/happiness/fulfilment, enjoying life) life
management// coping(setting goals/having plans/planning for the future, realizing goals/working on tasks/starting new things, coping active or passive), financial resources(having money/wealth, financial security, retirement fund) aging/age as a topic(money/wealth not needed, acceptance of age/aging/death/dying, becoming old, thinking about/anticipating age/aging/ death/dying, remaining young, ignoring age/aging/death/dying) independence(independent without further, specification, autonomy, physical independence/mobility), meaning in life(religion, a life worth living) growth/maturation, respect/status, ence/mobility), meaning in life(religion, a life worth living) growth/maturation, respect/status,
respect/status, education/knowledge(education, knowledge about life in general) microenvironment(environment (not further specified or Social, positive role models, family upbringing) ronment(environment (not further specified or Social, positive role models, family upbringing)
society/macro environment (social policy (health/work/education retirement policy), policy/society (not further specified), negative aging stereotypes, newspaper/TV

Iran $\quad$ Availability of support system (supportive policies, culture, welfare facilities, family background and relationships, social interaction), state of health, personal capabilities (gaine experiences, efficacy), personality characteristics(attitude, personal beliefs, temperament), lifestyle(life management, healthy lifestyle)

Positive perspective and coping, active independence, health, relationships with people, freedom, beneficial contribution, relationship with God, comfort resources

Troutman(2014)

Secondary

qualitative

analysis

$\begin{array}{cc}\text { Cosco et } & \text { Systematic } \\ \mathrm{al}(2014) & \text { review }\end{array}$

311 older adults $(60+)$

84 quantitative studies and 26 qualitative

studies

9

Topaz et

al(2014)

Literature

review

Nguyen \& Seal 2014

Qualitative approach

44 elders

Systematic

26 qualitative

article

review

Concept analysis

McCarthy and

Bockweg(2013)

Horder et
al(2013)

$\begin{array}{cc}\text { Qualitative } & 24 \text { community- } \\ \text { content analysis } & \text { dwelling older }\end{array}$

(77-90 years

old)
Biomedical(physical functioning/disability, cognitive functioning/disability, affective status, presence/probability of disease, mental health, longevity); psychosocial( personal resources, engagement, life satisfaction/well-being, support system, independence/ autonomy); extrinsic factors(environment/finances)

USA Meaning purpose in life: gerotranscendence(decreased death anxiety, meaningful activities, self-acceptance, relationships, solitude, wisdom) spirituality(spiritual Perspective, religiosity) intrapsychic factors (creativity, low level), negative affectivity, personal control), functional performance mechanisms(health promotion activities, physical health, physical mobility)

performance mechanisms (health promotion activities, physical health, physical mobility)
Chinese elders emphasized physical health and mobility, mental health, positive attitudes, shedding responsibilities, positive family relationships, financial stability, social engagement, religious faith, and accomplishments and volunteer work. Hmong elders emphasized physical health and mobility, mental health, harmonious relationships, positive family relationships,

UK Biomedical(cognitive and mental, psychological health and functioning, health maintenance behavior, health and longevity); external factors(environmental factors, finance), psychosocial (engagement, perspective, self-awareness, independence, acceptance, quality of life, prevention and remediation, community, spirituality, social roles, maintenance, adjustment)

USA Transcendence(relationships, creativity, introspection, contemplation, and spirituality)

Sweden Themes: Self-respect through ability to keep fear of frailty at a distance

Categories: Having sufficient bodily resources for security and opportunities, structures that promote security and opportunities(satisfaction with one's financial situation, security and opportunities in the closest context, the health and well-being of close relatives and friends) feeling valuable in relation to the outside world(feeling noticed and appreciated in socia relations, engagement in activities that provide pleasure or benefit), choosing gratitude instead of worries(choosing gratitude for not being as bad as others who are in a worse situation, denying difficulties, accepting things you cannot change) maintaining physical, mental, and relational well-being; living a healthy life, and living a
faithful life tangible family support, financial stability, social engagement, and religious faith

(2013)




\section{Table B. Cntd}

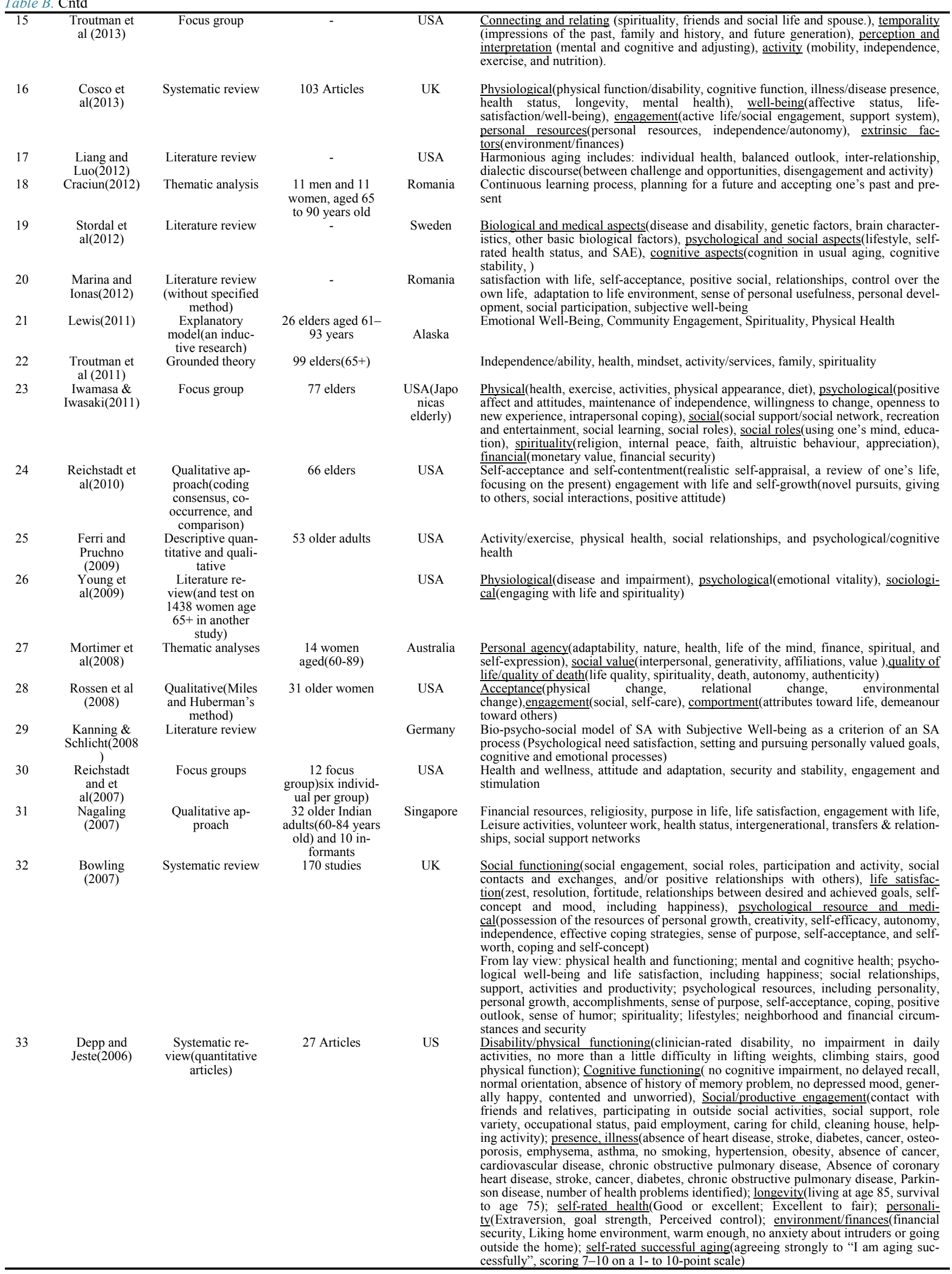




\begin{tabular}{|c|c|c|c|c|c|}
\hline \multicolumn{6}{|c|}{ Table B. Cntd } \\
\hline 34 & $\begin{array}{l}\text { Bowling, and } \\
\text { Dieppe(2005) }\end{array}$ & $\begin{array}{c}\text { Systematic litera- } \\
\text { ture } \\
\text { review }\end{array}$ & 170 articles & UK & $\begin{array}{l}\text { Theoretical definitions: life expectancy, life satisfaction and wellbeing } \\
\text { (includes happiness and contentment), mental and psychological health, } \\
\text { cognitive function, personal growth, learning new things, physical health } \\
\text { and functioning, independent functioning, psychological characteristics } \\
\text { and resources, including perceived autonomy, control, independence, } \\
\text { adaptability, coping, self-esteem, positive outlook, goals, sense of self, } \\
\text { social community, leisure activities, integration and participation, social } \\
\text { networks, support, participation, activity } \\
\text { Additional lay definitions: accomplishments, enjoyment of diet, financial } \\
\text { security, neighborhood, physical appearance, productivity and contribu- } \\
\text { tion to life, sense of humor, sense of purpose, spirituality }\end{array}$ \\
\hline 35 & $\begin{array}{c}\text { Knight and } \\
\text { Ric- } \\
\text { ciardelli(2003) }\end{array}$ & Content analysis & $\begin{array}{l}60 \text { older adults } \\
\text { (ages of } 70 \text { and } \\
101 \text { years) }\end{array}$ & Australia & $\begin{array}{l}\text { Health, Activity, Personal Growth, Happiness/ contentment, Relation- } \\
\text { ships, Independence, Appreciation/ value of life, Longevity }\end{array}$ \\
\hline 36 & $\begin{array}{l}\text { Baltes and Baltes } \\
\quad(1990,2003)\end{array}$ & $\begin{array}{l}\text { Literature review } \\
\text { (Test quantitative- } \\
\text { ly among 244) }\end{array}$ & - & Germany & $\begin{array}{l}\text { Selection(elective and loss-based concerns directionality of development } \\
\text { including selection of alternative outcomes and goal structures) } \\
\text { Optimization concerns(achieving desired outcomes (attaining higher } \\
\text { levels of functioning)) } \\
\text { Compensation concerns(activation or acquisition of new means for coun- } \\
\text { teracting loss/decline in means that threatens the maintenance of a given } \\
\text { level of functioning) }\end{array}$ \\
\hline 37 & $\begin{array}{c}\text { Crowther et al } \\
(2002)\end{array}$ & Literature review & - & USA & $\begin{array}{l}\text { Minimize risk and disability; engage in active life, maximize positive } \\
\text { spirituality, maximize physical and mental ability }\end{array}$ \\
\hline 38 & Flood(2002) & Concept analysis & - & USA & Life satisfaction, functional status, gerotranscendence, spirituality \\
\hline 39 & $\begin{array}{l}\text { Rowe and Kahn } \\
\text { (1997) }\end{array}$ & $\begin{array}{l}\text { Theory develop- } \\
\text { ment }\end{array}$ & - & USA & $\begin{array}{l}\text { Avoiding disease and disability, engagement with life, high cognitive and } \\
\text { physical function }\end{array}$ \\
\hline 40 & Ryff(1989) & Literature review & - & USA & $\begin{array}{l}\text { Well-being (Self-Acceptance, Positive Relations with Others, Autonomy, } \\
\text { Environmental Mastery, Purpose in Life, Personal Growth) }\end{array}$ \\
\hline 41 & $\begin{array}{c}\text { Hav- } \\
\text { ighurst(1961) }\end{array}$ & Literature review & - & USA & $\begin{array}{l}\text { Life satisfaction(Zest Vs. apathy; resolution and fortitude; goodness of fit } \\
\text { between desired and achieved goals; positive self-concept; mood tone) }\end{array}$ \\
\hline
\end{tabular}

